International Journal of Business Management and Economic Review

Vol. 4, No. 02; 2021

ISSN: 2581-4664

\title{
THE ROLE OF TECHNOLOGY AWARENESS AND AGE IN MODERATING THE FACTORS AFFECTING CASHLESS USE BEHAVIOR : STUDY ON BRIZZI CARD OF PT. BANK RAKYAT INDONESIA IN BANDA ACEH
}

\author{
*Yusrizal, PermanaHonneytaLubis, Syafruddin \\ Management Department, UniversitasSyiah Kuala, Indonesia \\ http://doi.org/10.35409/IJBMER.2021.3241
}

\begin{abstract}
Changes in payment instruments are driven by advances in digital technology, shifting the role of cash as a means of payment to more efficient and economical forms of non-cash payments. The purpose of this study is to look at the effect of performance expectancy, social influence and facilitating condition on cashless intention behavior and their impact simultaneously on cashless use behavior. The population was the users of the BRIZZI card of PT. Bank Rakyat Indonesia in the branch of Banda Aceh. This study used a sample technique with stratified random sampling method and provided the sample as much as 160 people. The results showed that of the 7 direct hypotheses that were all accepted because they had CR and P values that had met the requirements. The results of indirect hypothesis testing namely performance expectancy, social influence and facilitating condition on cashless use behavior through cashless intention behavior are significant. The role of cashless intention behavior in the research model is as the partial mediator. In the measurement, the cashless intention behavior has the greatest magnitude, so this variable needs to be maintained so that its contribution in increasing cashless use behavior during periods will come consistently. The novelty in this study lies in the use of technological awareness and age as moderation variables. This contributes to enrich and update the causality theories in management, and also the research model tested can be as a reference for practitioners especially for the leaders in PT. Bank Rakyat Indonesia in Banda Aceh.
\end{abstract}

Keyword:Performance Expectancy, Social Influence, Facilitating Condition, Cashless Intention Behavior, Cashless Use Behavior.

\section{INTRODUCTION}

The development of information and communication technology nowadays makes it easier to conduct transactions. In line with rapid technological developments, people's lifestyles and payment systems in economic transactions continue to change. Significant changes were seen in the pattern of changes in payment instruments driven by advances in digital technology, shifting the role of cash as a means of payment to more efficient and economical forms of non-cash payments.

Electronic money (electronic money) is money that is used in internet transactions by electronic means. Electronic money has a stored value (stored value) or prepaid (prepaid) where a certain amount of money is stored in an electronic media owned by someone. Electronic money is classified as a new innovation. Among the people there are still many who consider electronic 


\section{International Journal of Business Management and Economic Review}

Vol. 4, No. 02; 2021

ISSN: 2581-4664

money the same as other types of cards issued by banks such as debit cards and credit cards. Whereas in terms of usage it is clearly different, electronic money has facilities that are used without having to be bothered with a personal identification number (PIN). Thus, ATM cards and credit cards are not classified as electronic money. From the data table below, it can be seen that more and more institutions are issuing electronic money products.

Table 1. Provider of Electronic Money in Indonesia

\begin{tabular}{|l|l|l|}
\hline No. & \multicolumn{1}{|c|}{ Provider } & \multicolumn{1}{c|}{ Product Name } \\
\hline 1. & Bank Rakyat Indonesia (BRI) & BRIZZI \\
\hline 2. & Bank Mandiri & E - Money dan E - Toll Card \\
\hline 3. & Bank Central Asia (BCA) & Flazz \\
\hline 4. & Bank Mega & Mega Cash \\
\hline 5. & Bank Negara Indonesia (BNI) & TapCash \\
\hline 6. & Bank DKI & Jak Card \\
\hline 7. & Bank Permata & BBM Money \\
\hline 8. & CIMB Niaga & RekeningPonsel \\
\hline 9. & PT. Bank National Nobu & Nobu E-Money \\
\hline 10. & Telkomsel & T - Cash \\
\hline 11. & Indosat & Dompetku \\
\hline 12. & XL Axiata & XL Tunai \\
\hline 13. & Nusa IntiArta & DokuWallet \\
\hline 14. & Telkom Indonesia & T - Money dan Telkom Delima \\
\hline 15. & Skye Sab & Skye Mobile Money \\
\hline 16. & Finnet Indonesia & Finpay \\
\hline 17. & Artajasa & MYNT E - Money \\
\hline
\end{tabular}

Source : www.bi.go.id (2019)

The low interest in using BRIZZI among PT. Bank Rakyat Indonesia (BRI) customers is partly due to the performance expectancy for BRIZZI products that they know and hear about which they do not see as their expectations. (Sair, SA, \& Danish, RQ (2018). Other causes are about Social Influence which has not encouraged the community to immediately use BRIZZI, and the media facilities of BRIZZI users themselves both for top ups and for uneven spending places in all retails. Existing stores are thought to have contributed to the low interest of BRI customers in using BRIZZI e money, (Zhang et al., 2014).

\section{LITERATURE REVIEW}

\section{Cashless Use Behavior}

(Alma, 2013) stated that the purchase decision is is a consumer decision that is influenced by the financial economy, technology, politics, culture, products, prices, location, promotion, physical evidence, people and, process. Thus forming an attitude on consumers to process all information and draw conclusions in the form of responses that appear what products will be purchased ". (Kotler and Armstrong, 2017) defined the stage one of the purchase decision starts from recognition of a particular problem or need and here the buyer has a need to be 


\section{International Journal of Business Management and Economic Review}

Vol. 4, No. 02; 2021

ISSN: 2581-4664

satisfied or has a problem that needs to be resolved, and this is the beginning of the buyer's decision process. Purchasing decisions are inseparable from the nature of a consumer (consumer behavior) so that each consumer has different habits in making purchases.

\section{Cashless Intention Behavior}

Cashless Intention Behavior is the buying interest behavior shown by BRI customers in responding the offer made by BRI for BRIZZI product, so the discussion of theory refers to buying interest. According to (Schiffman and Kanuk, 2010), Purchase Interest is a model of a person's attitude towards the object of goods which is very suitable in measuring attitudes towards a certain class of products, services, or brands. According to (Kotler and Keller, 2018), Purchase Interest is something that arises after receiving a stimulus from the product he sees, from there arises an interest in trying the product until it finally arises the desire to buy in order to have it.

\section{Performance Expectancy}

Performance expectations (performance expectancy) is defined as how high a person / individual believes that functioning the technological innovation will be able to help him to get a variety of profits. Individual performance is expected to be aligned with organizational performance. Performance expectancy is a person's belief that if he uses technology it will improve his performance at work (Venkatesh, Thong and $\mathrm{Xu}, 2012$ ).

\section{Social Influence}

Social factors are the dominant variable of the intention to use technological innovation as illustrated by the representation of a number of important variables that are built related to normative originating from a group of behaviors constructed against interpersonal agreements made by someone with others in certain social situations (Fischer, 2015) and (Vannoy and Palvia, 2010). Social factors mean that a person / individual has perceived himself with the belief that his interests will influence using the system / innovation.

\section{Facilitating Condition}

Facility condition variable is defined as how far an innovation is believed as something that can still be relied upon by the value of compatibility and needs of potential users. Facility condition variable is also defined as how much a person believes that the facilities and infrastructure available can support the system on an organizational (Goldsmith, 2015). The concept of facility condition such as the perception of behavioral control which is a reflection that the limitation from within and outside a person on behavior include his own perception (self-efficacy), the state of the condition of resource facilities and the existence of the condition of the facility.

\section{Research paradigm}

The paradigm or relationship between concepts (variables) in this study and also the hypotheses can be illustrated below. 
Vol. 4, No. 02; 2021

ISSN: 2581-4664

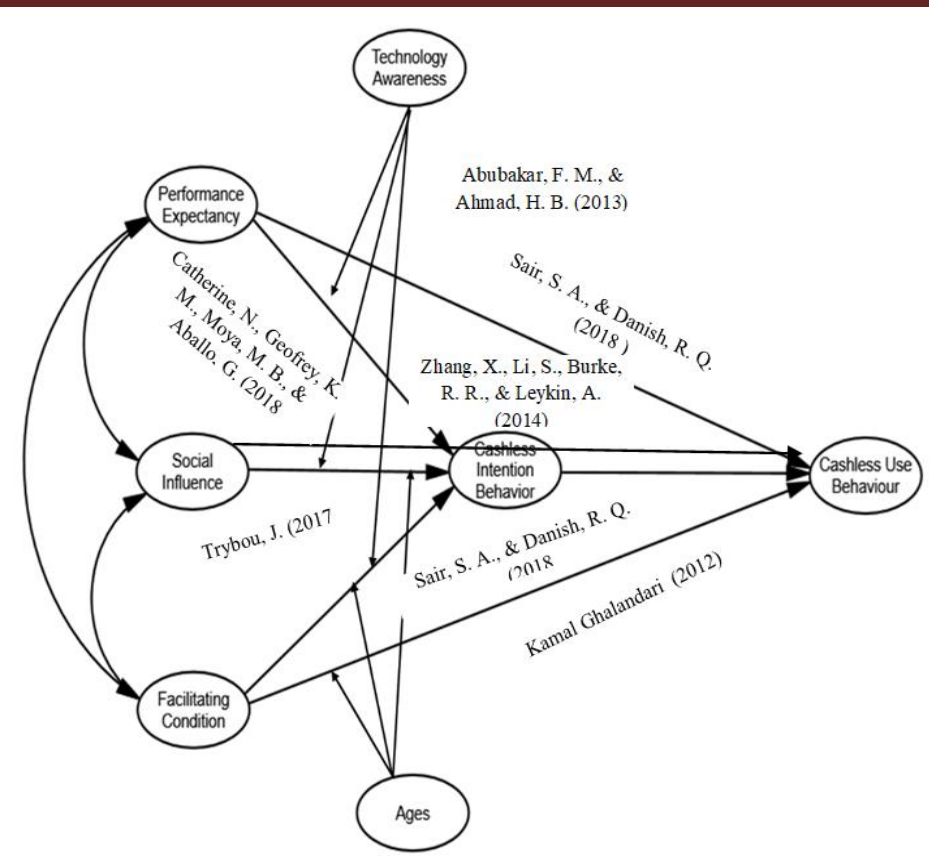

Figure 1.Research Paradigm

H1: Performance expectancy, social influence, facilitating condition, cashless intention behaviorand the cashless use behavior in in using BRIZZI card in Banda Aceh is good

H2: Performance expectancy affects cashless intention behavior in using BRIZZI card

H3: Social influence affects the cashless intention behavior in using BRIZZI card

H4: Facilitating condition affects the cashless intention behavior in using BRIZZI card

H5: Performance expectancy affects the cashless use behavior in using BRIZZI card

H6: Social influence affects the cashless use behavior in using BRIZZI card

H7: Facilitating condition affects the cashless use behavior in using BRIZZI card

H8: Cashless intention behavior affects the cashless use behavior in using BRIZZI card

H9: Performance expectancy affects the cashless use behavior through the cashless intention behavior in using BRIZZI card

H10: Facilitationg condition affects the cashless use behavior through cashless intention behavior in using BRIZZI card

H11: There is real difference for those who have a higher level of technology awareness compared to a lower in the effect of performance expectancy on the cashless intention behavior in using BRIZZI card

H12: there is a real difference for those who have a higher level of technology awareness compared to a lower in the effect of social influence on cashless intention behavior in using BRIZZI card

H13: It is suspected that there is a real difference for those who have a higher level of technology awareness compared to a lower in the effect of facilitating condition on the cashless intention behavior in using BRIZZI card 


\section{International Journal of Business Management and Economic Review}

Vol. 4, No. 02; 2021

ISSN: 2581-4664

H14: It is suspected that there are real difference for those who have a higher age level than those the lower in the effect of performance expectancy on the cashless intention behavior in using BRIZZI card

H15: It is suspected that there is a real difference for those who have a higher age level than the lower in the effect of social influence on cashless intention behavior in using BRIZZI card

H16: there is a real difference for those who have a higher age level than the lower in the effect of facilitating condition on the cashless intention behavior in using BRIZZI card

\section{RESEARCH METHOD}

\section{Location and Research Object}

This research was carried out at PT. Bank Rakyat Indonesia in branch of Banda Aceh (PT. BRI Banda Aceh). The object was the users of the BRIZZI card in the city of Banda Aceh. The variables are the performance expectancy, social influence, facilitating condition, cashless intention behaviour, cashless use behavior, technology awareness and age.

\section{Sampling}

The population was the users of the BRIZZI card in Banda Aceh. This study used a sample technique with stratified random sampling method. In SEM analysis the minimum number of sample to be taken is 5 times the number of indicator variables used (Ferdinand, 2014),. So that the minimum sample size in the study was 150 people (30 indicators $x$ 5), but in this study the authors took a sample of 160 people to avoid the occurrence of errors, because the total population is more than the number of samples.

\section{Data analysis method}

The descriptive hypothesis was tested with One sample T-Test. The direct effects were tested with the structural equation model (SEM) technique, which is a multivariate statistical analysis technique to be able to analyze not only the influence between variables, but also the relationship of variables with their respective indicators. The criteria for accepting Ha are Critical Ratio (CR)> 1.96 and Probability value $(\mathrm{P})<0.05$. For the indirect effects, this study used Sobel test to measure the mediation effect. And for the Moderation effects, this study used the comparison model through Amos software.

\section{RESULT}

\section{Descriptive Analysis}

Hypothesis 1 (descriptive) is performed using one sample test with a cut-off value of 3.4 (the interval Likert scale limitation of the good ones) with the following result:

\section{Tabel 2. One Sample T Test}

\begin{tabular}{|l|l|l|l|l|l|l|}
\hline \multirow{2}{*}{} & \multicolumn{6}{|l|}{ Test Value $=3.4$} \\
\hline & & df & $\begin{array}{l}\text { Sig. } \\
(2- \\
\text { tailed })\end{array}$ & $\begin{array}{l}\text { Mean } \\
\text { Differenc }\end{array}$ & $\begin{array}{l}\text { 95\% } \\
\text { Interval }\end{array}$ & $\begin{array}{l}\text { Confidence } \\
\text { Difference }\end{array}$ \\
\cline { 5 - 6 } & & & Lower the & Upper \\
\hline
\end{tabular}




\begin{tabular}{|c|c|c|c|c|c|c|}
\hline $\begin{array}{l}\text { Performance } \\
\text { Expectancy }\end{array}$ & 8.789 & 159 & 0.000 & 0.570 & 0.44 & 0.70 \\
\hline Social Influence & 11.062 & 159 & 0.000 & 0.661 & 0.54 & 0.78 \\
\hline Facilitating Condition & 8.897 & 159 & 0.000 & 0.491 & 0.38 & 0.60 \\
\hline $\begin{array}{l}\text { Cashless } \\
\text { Behavior }\end{array}$ & 9.548 & 159 & 0.000 & 0.570 & 0.45 & 0.69 \\
\hline Cashless Use Behavior & 12.866 & 159 & 0.000 & 0.766 & 0.65 & 0.88 \\
\hline
\end{tabular}

From Table 2 above, it can be seen that the significance level with alpha 5\% is all below 0.05 so that it explains that all variables in this study are Performance Expectancy, Social Influence, Facilitating Condition, Cashless Intention Behavior and Cashless Use Behavior are good. Thus rejecting $\mathrm{H} 0$ and accepting $\mathrm{Ha}$ (All variables are in good conditions).

\section{Loading Factor with measurement test}

Testing the validity of the loading factor can be seen in the following figure and table:

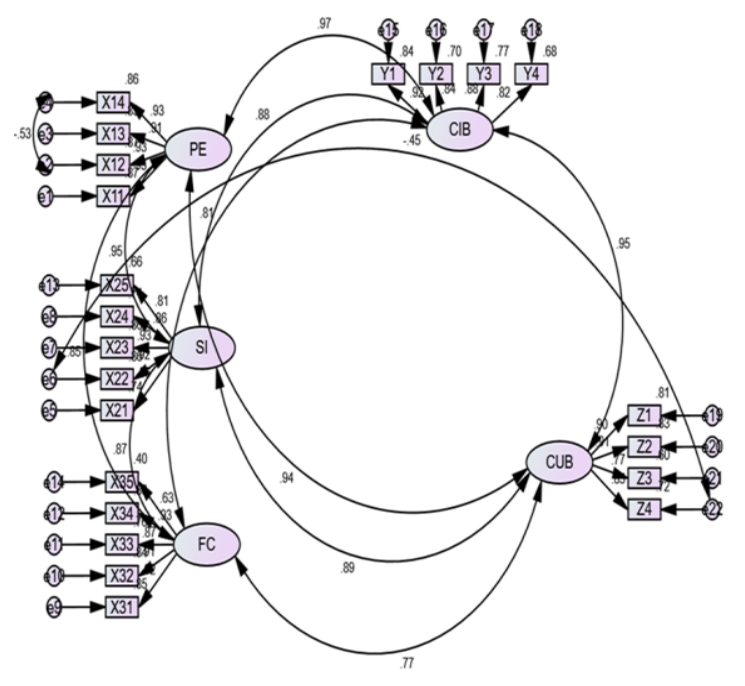

Figure 2.Loading Factor

Measurement test result indicates that several indicators of the research variable have a loading factor value below 0.5 . The following table is the result of a net measurement test which can later be included in structural testing.

Table 3. Loading Factor

\begin{tabular}{|l|l|l|l|l|}
\hline No & Indicator & & Variable & Estimate \\
\hline 1 & X11 & $<---$ & PE & .942 \\
\hline 2 & X12 & $<---$ & PE & .921 \\
\hline 3 & X13 & $<---$ & PE & 859 \\
\hline 4 & X14 & $<---$ & PE & .922 \\
\hline
\end{tabular}


Vol. 4, No. 02; 2021

ISSN: 2581-4664

\begin{tabular}{|c|c|c|c|c|}
\hline No & Indicator & & Variable & Estimate \\
\hline 5 & X21 & <-- & SI & .917 \\
\hline 6 & X22 & <-- & SI & 874 \\
\hline 7 & $\mathrm{X} 23$ & <--- & SI & .923 \\
\hline 8 & $\mathrm{X} 24$ & <--- & SI & .814 \\
\hline 9 & X31 & $<--$ & FC & .635 \\
\hline 10 & X32 & $<--$ & FC & 922 \\
\hline 11 & X33 & $<--$ & FC & 839 \\
\hline 12 & X34 & <-- & FC & .879 \\
\hline 13 & $\mathrm{X} 25$ & $<--$ & SI & 822 \\
\hline 14 & X35 & $<--$ & FC & .942 \\
\hline 15 & $\mathrm{Y} 1$ & <-- & CIB & .921 \\
\hline 16 & $\mathrm{Y} 2$ & <-- & CIB & 859 \\
\hline 17 & $\mathrm{Y} 3$ & <--- & CIB & .922 \\
\hline 18 & Y4 & <--- & CIB & .917 \\
\hline \begin{tabular}{|l|}
19 \\
\end{tabular} & $\mathrm{Z} 1$ & <--- & CUB & 898 \\
\hline 20 & $\mathrm{Z} 2$ & <--- & CUB & .912 \\
\hline 21 & $\mathrm{Z3}$ & <--- & CUB & .786 \\
\hline 22 & Z4 & K--- & CUB & .882 \\
\hline
\end{tabular}

Table 3 shows the loading factors of all the indicators in the model, and are eligible for further processing because they have a loading factor $>0.5$.

Table 4.Goodness of Fit Criteria Table

\begin{tabular}{|l|l|l|l|}
\hline $\begin{array}{l}\text { Size Index } \\
\text { Criteria }\end{array}$ & Cut-off Value & Analysis Results & Model Evaluation \\
\hline Chi Square & Expected to be small & 385,182 & Fit \\
\hline CMIN / DF & CMIN / DF $<2$ & 1955 & Fit \\
\hline GFI & $\geq 0.90$ & 0.905 & Fit \\
\hline AGFI & $\geq 0.90$ & 0850 & Well \\
\hline RMSEA & $<0.08$ & 0.073 & Fit \\
\hline
\end{tabular}

The table 4 explains that the model in this research fits the criteria of the Goodness of Fit. So the test can be continued to the direct test, indirect test, and also moderation test.

\section{Structural Analysis of Direct Testing}

The results of structural tests carried out have produced the information needed to answer hypotheses that have been built before whether proven or not. Figure 3 below illustrates the influence between variables: 


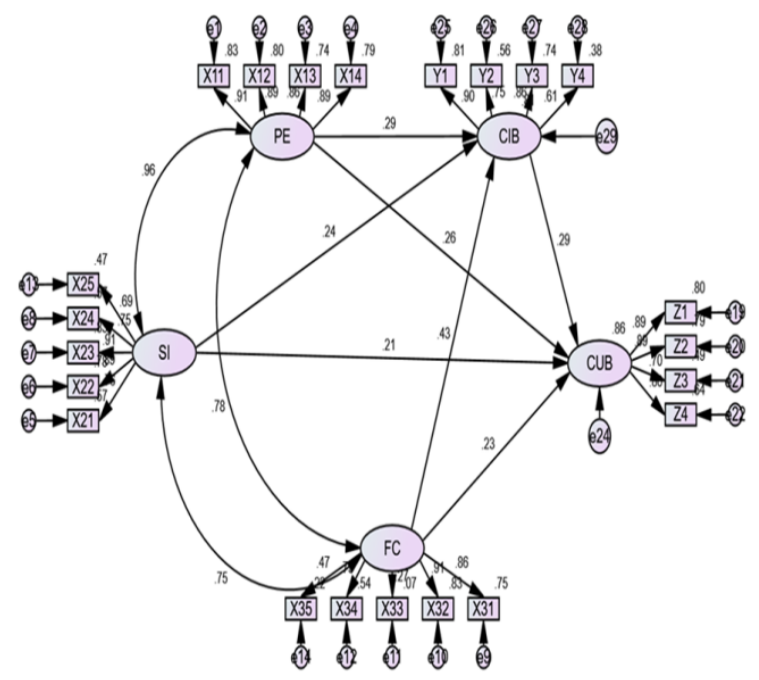

Figure 3.Structural Equation Model

Based on Figure 3, it explains the influence of each variable, namely performance expectancy, social influence, facilitating condition, cashless intention behavior and cashless use behavior. An overview of all hypothesis testing together with the results can be seen in the following Table 3:

\section{Table 5 Direct Hypothesis Result}

\begin{tabular}{|c|l|l|l|l|}
\hline No & Hypothesis & $\begin{array}{l}\text { CR Cut } \\
\text { off }>\mathbf{1 . 9 6}\end{array}$ & $\begin{array}{l}\text { P value } \\
\text { Cut off <0.05 }\end{array}$ & Information \\
\hline 1 & $\begin{array}{l}\text { There is the effect of performance } \\
\text { expectancy on cashless intention } \\
\text { behavior }\end{array}$ & 8,857 & $* * *$ & 0.29 \\
\hline 2 & $\begin{array}{l}\text { There is the effect of social influence } \\
\text { expectancy on cashless intention } \\
\text { behavior }\end{array}$ & 8077 & $* * *$ & 0.239 \\
\hline 3 & $\begin{array}{l}\text { There is the effect of facilitating } \\
\text { condition on cashless intention behavior }\end{array}$ & 11,107 & $* * *$ & 0.431 \\
\hline 4 & $\begin{array}{l}\text { There is the effect of performance } \\
\text { expectancy on cashless use behavior }\end{array}$ & 17,773 & $* * *$ & 0.259 \\
\hline 5 & $\begin{array}{l}\text { There is the effect of social influence on } \\
\text { cashless use behavior }\end{array}$ & 9,219 & $* * *$ & 0.213 \\
\hline 6 & $\begin{array}{l}\text { There is the effect of facilitating } \\
\text { condition on cashless use behavior }\end{array}$ & 10,105 & $* * *$ & 0.231 \\
\hline 7 & $\begin{array}{l}\text { There is the effect of cashless intention } \\
\text { behavior on cashless use behavior }\end{array}$ & 18,193 & $* * *$ & 0.287 \\
\hline
\end{tabular}


Seen from the 7 direct hypotheses available, all of the results are accepted and significant because they have a CR value of 1.96 and a $\mathrm{P}$ value $<0.05$ that meet the minimum requirements of the accepted hypothesis. In other words, the independent variable, namely performance expectancy, social influence, and facilitating condition, has an influence to increase the dependent variable, namely cashless use behavior as long as the independent variable can be improved by the leadership or management of PT. BRI Banda Aceh.

\section{Structural Analysis of Indirect Testing}

The following is an indirect hypothesis conclusion that is the effect of performance expectancy, social influence and facilitating condition on cashless use behavior through cashless intention behavior as shown in Table 4 below:

Table 6.Indirect Hypothesis Result

\begin{tabular}{|c|l|l|l|l|l|}
\hline No & Indirect Hypothesis & $\begin{array}{l}\mathbf{P} \text { value } \\
<\mathbf{0 . 0 5}\end{array}$ & Beta & Information & $\begin{array}{l}\text { The Role of } \\
\text { Mediation }\end{array}$ \\
\hline 1 & $\begin{array}{l}\text { The Effect of Performance } \\
\text { Expectancy on Cashless Use } \\
\text { Behavior through Cashless } \\
\text { Intention Behavior }\end{array}$ & 0.000 & $8.30 \%$ & Accepted & $\begin{array}{l}\text { Partial } \\
\text { Mediating }\end{array}$ \\
\hline 2 & $\begin{array}{l}\text { The Effect of Social Influence on } \\
\text { Cashless Use Behavior through } \\
\text { Cashless Intention Behavior }\end{array}$ & 0.000 & $6.85 \%$ & Accepted & $\begin{array}{l}\text { Partial } \\
\text { Mediating }\end{array}$ \\
\hline 3 & $\begin{array}{l}\text { The Effect of Facilitating } \\
\text { Condition on Cashless Use } \\
\text { Behavior through Cashless } \\
\text { Intention Behavior 0.000 }\end{array}$ & $12.36 \%$ & Accepted & $\begin{array}{l}\text { Partial } \\
\text { Mediating }\end{array}$ \\
\hline
\end{tabular}

The influences of Performance expectancy, social influence and facilitating condition on cashless use behavior are significant while the influences of performance expectancy, social influence and facilitating condition on cashless use behavior through cashless intention behavior are also significant. The influences both directly and through cashless intention behavior are significant, then the role of cashless intention behavior variable here is as a partial mediator.

\section{Moderation Testing}

Hypothesis of Technology awareness as moderation

The results of the Chi square comparison can be seen in the following table: 
International Journal of Business Management and Economic Review

Vol. 4, No. 02; 2021

ISSN: 2581-4664

\section{Table 7. Technology Awareness as a differentiator for full model}

\begin{tabular}{|l|l|l|l|}
\hline Model & DF & CMIN & P \\
\hline Structural weights & 46 & 82.879 & .001 \\
\hline
\end{tabular}

From Table 5 above it describes that the $\mathrm{p}$ value is $0.001<0.05$ so that it can be said to accept $\mathrm{Ha}$ and reject $\mathrm{Ho}$, in other words there is a significant difference between the full model of the high technological awareness group and the low one.

Hypothesis of age as moderation

The results of the Chi square comparison can be seen in the following table:

Table 8. Age as a differentiator for full model

\begin{tabular}{|l|lll|}
\hline Model & DF & CMIN & P \\
\hline Structural weights & 46 & 114.541 & .000 \\
\hline
\end{tabular}

From Table 6 above it can be seen that the $\mathrm{p}$ value is $0.000<0.05$ so that it can be said to accept $\mathrm{Ha}$ and reject Ho, in other words there is a significant difference between the full model of the high age group compared with the low age group.

\section{CONCLUSION}

Some conclusion can be figured in this research, are :

1. Descriptive test results found that all variables studied and included in this research model have a significance level with alpha 5\% all below the cut-off rate so that it concludes that all variables in this study are Performance Expectancy (PE), Social Influence (SI), Facilitating Condition (FC), Cashless Intention Behavior (CIB) and Cashless Use Behavior (CUB) are good. Of the five variables when viewed descriptively, the highest average is the Cashless Use Behavior (CUB) variable, so it can be concluded that this variable is best appreciated by BRI customers.

2. When it is viewed from the 7 direct hypotheses tested, all results show a positive and significant effect, because they have CR or P numbers or values that are included in the recommended values. The influence of Social Influence on Cashless Intention Behavior is also significant. This means that if you want to increase Cashless Intention Behavior, it can be done through increasing Social Influence. Likewise, the effect of Facilitating Condition on Cashless Intention Behavior is significant.

3. Of the 3 indirect influences that want to be seen, namely how the role of CIB in mediating the PE, SI and FC variables on CUB turned out to be all significant. However, because the direct effect is also significant, the CIB variable only acts as a partial mediating effect on these three types of indirect influence relationships.

4. While the moderation hypothesis that tests the role of the Technological Awareness (TA) variable that functions as a dummy variable in distinguishing groups with high TA to low TA, the full model had a significant effect.. However, when viewed path by path, 


\section{International Journal of Business Management and Economic Review}

Vol. 4, No. 02; 2021

ISSN: 2581-4664

especially the independent paths of PE, SI and FC against CIB it will produce different results.

Several suggestion that can be mapped as follows.

1. Of all the determinant variables, the CIB variable with the highest magnitude is seen so that the impact to increase CUB is also the biggest one. This variable needs to be maintained continuously so that its contribution in increasing CUB in the future will remain consistent.

2. The managerial implication based on all findings is that management can choose which variables in the segment should be intervened to increase CUB.

\section{REFERENCES}

Alma, B. (2013) Manajemen Pemasaran dan Pemasaran Jasa. Revisi. Bandung: Alfabeta.

Ferdinand, A. (2014) Metode Penelitian Manajemen. Edisi 5. Semarang: Universitas Diponegoro.

Fischer, R. (2015) 'Rewarding Employee Loyalty: an Organizational Justice Approach', International Journal of Organisational Behaviour, 8(3), pp. 486-503. doi: 10.18535/ijsrm/v5i12.03.

Goldsmith, E. B. (2015) 'Social Influence History and Theories', in International Series on Consumer Science. Boston: Springer, pp. 23-39. doi: https://doi.org/10.1007.

Kotler, P. and Armstrong, G. (2017) Principles of Marketing. 17th edn. London: Pearson.

Kotler, P. and Keller, K. L. (2018) Marketing Management, Global Edition. 15th editi. Harlow, United Kingdom: Pearson.

Schiffman, L. and Kanuk, L. (2010) Consumer Behavior. 11th edn. London: Pearson.

Vannoy, S. A. and Palvia, P. (2010) 'The Social Influence Model of Technology Adoption', Communications of the ACM, 53(6), pp. 149-153.

Venkatesh, V., Thong, J. Y. L. and Xu, X. (2012) 'Consumer Acceptance and Use of Information Technology: Extending the Unified Theory of Acceptance and Use of Technology', MIS Quarterly, 36(1), pp. 157-178. doi: 10.2307/41410412.

Zhang, X. L. et al. (2014) 'An Examination of Social Influence on Shopper Behavior Using Video Tracking Data', Journal of Marketing, 78(5), pp. 24-41. doi: 10.1509/jm.12.0106. 